\title{
Teachers' Perception Towards The Use of Tarsia Puzzle to Create Joyful Learning of Mathematics
}

\section{Persepsi Guru terhadap Penggunaan Puzzle Tarsia untuk Menciptakan Pembelajaran Matematika yang Menyenangkan}

\section{Nur Qomaria ${ }^{1 *}$}

1Universitas Trunojoyo Madura

*Email Korespondensi: nur.qomaria@trunojoyo.ac.id

\begin{tabular}{lll}
\hline \hline Info Artikel & \\
\hline Diterima & $:$ & 31 Jan 21 \\
Direvisi & $:$ & 17 Feb 21 \\
Diterbitkan & $:$ & 28 Feb 21 \\
& & \\
& & \\
\end{tabular}

\section{Kata Kunci:}

Elementary School, Joyful

Learning, Tarsia Puzzle

\section{Cara merujuk artikel ini:}

Qomaria, N. (2021). Teachers' Perception Towards The Use of Tarsia Puzzle to Create Joyful Learning of Mathematics. Vygotsky: Jurnal Pendidikan Matematika dan Matematika, 3 (1), 13-24.

Diunduh dari https://jurnalpendidikan. unisla.ac.id/index.php/ $\mathrm{VoJ} /$ article/view/347

\begin{abstract}
This research aims to determine whether Tarsia puzzle can be used to create joyful learning of mathematics according to elementary school teachers' perception. Forty two elementary school teachers who teach at different schools in Bangkalan, Madura were surveyed. In this survey research, data about teachers' perception were collected using a questionnaire with 16 close-ended items (Likert Scale 1 - 4). Descriptive statistics consisting of percentages and means were used to analyze the data. The results showed that teachers agreed that Tarsia puzzle can help teachers to create joyful learning of mathematics in elementary school. However, some of them stated that they had lack confidence and competence in using Formulator Tarsia.
\end{abstract}

\begin{tabular}{l}
\hline Abstrak \\
\hline Penelitian ini bertujuan untuk mengetahui apakah \\
puzzle Tarsia dapat digunakan untuk menciptakan \\
pembelajaran matematika yang menyenangkan \\
menurut persepsi guru sekolah dasar. Survei \\
dilakukan terhadap empat puluh dua guru sekolah \\
dasar yang mengajar di berbagai sekolah di \\
Bangkalan, Madura. Dalam penelitian survei ini, \\
data tentang persepsi guru dikumpulkan melalui \\
kuesioner dengan 16 pernyataan tertutup (Skala \\
Likert 1 - 4). Statistik deskriptif yang terdiri dari \\
persentase dan rata-rata digunakan untuk \\
menganalisis data. Hasil penelitian menunjukkan \\
bahwa guru setuju bahwa puzzle Tarsia dapat \\
membantu guru menciptakan pembelajaran \\
matematika yang menyenangkan di sekolah dasar. \\
Namun beberapa diantaranya menyatakan kurang \\
percaya diri dan kurang kompeten dalam \\
menggunakan Formulator Tarsia.
\end{tabular}

Copyright (C) 2021 Vygotsky: Jurnal Pendidikan Matematika dan Matematika. All right reserved 


\section{INTRODUCTION}

Students often find difficulties in solving mathematical problems. PISA 2018 results show that Indonesia ranked 75th out of 80 countries. Mathematical average score for Indonesia is 379. This score is still far from the global mathematical average score of 489 (OECD, 2019). Simamora et al., (2018) found that the level of students' mathematics skills was still low and students were less interested in mathematics because they faced some difficulties to understand that subject. Teachers should give a strong mathematical foundation to students from an early age. UNESCO Institute for Statistics (2017) states the importance of gaining mathematical knowledge, especially for adolescents and children. This opinion is supported by Hasler \& Akshoomoff (2019) that every children should have basic mathematical skills. Education in COVID-19 pandemic bring many challenges to teachers, schools, students, and parents who have to adapt to the new strategy of teaching and learning. Some teachers reported that in distance learning, teachers need more effort to construct students' understanding than face-to-face learning (Rasmitadila, 2020; Putri et al., 2020). However, various attempts can be made to improve students' mathematical skills. Mathematics material at the elementary level can be taught by a fun method. Learning in a pleasant atmosphere can increase student motivation to master certain idea or concept (Widyawulandari et al., 2019). Another research also stated that teacher enjoyment of teaching mathematics in elementary schools has important effects on the mathematics teaching and learning process (Kirikkaya et al., 2010; Russo et al., 2020). Therefore, in any situation, both normal condition and this unpredictable crisis, the teacher must remain calm and be more creative in implementing fun method to keep students motivated and engaged in learning activities.

Joyful learning is one of the learning strategies that encourages student involvement in discussion, asking questions and team work. This learning concept emphasizes experiences that make students feel happy in each step of their learning (Wei et al., 2011). The fun atmosphere and no burden for teachers and students are the concept in joyful learning (Wei et al., 2011; Bhakti et al., 2019). A pleasant atmosphere encourages students to be actively engaged without feeling pressured. Joyful learning is a synergistic strategy and practice of active learning (Clark \& Mayer, 2008). This strategy can increase learning motivation and positive perceptions about learning (Ariawan \& Pratiwi, 2017). In practice, joyful learning is usually integrated with instructional media. Instructional media can help students visualize mathematical objects, so that they can understand the material more easily (Berney \& Bétrancourt, 2016). Instructional media can make the learning process more appealing (Cope, 2015) such as mathematical games, puzzles, hand - on activities, realistic and life related problem solving (Yabo, 2020; Putra, 2020).

One of the instructional media that can be used in learning mathematics in elementary schools is puzzle. Puzzle can be used to 
enhance comprehension of subject content, encourages collaborative learning and create a competitive environment in the classroom (Stoten, 2017). Puzzles in the learning process can be used to accomplish learning objectives and to foster students' general and specific mathematical abilities (Gorev, 2018). Sengul \& Argat (2015) suggested to use various teaching tools, especially puzzles, to help students with low academic performances. Another research found that puzzle game can bring out students' enthusiasm, thus encouraging their participation and stimulating their action in problem posing activities (Candiasa et al., 2018).

Puzzle as an instructional media contains problems related to a particular topic, for example Asri el al. (2020) used puzzle to help students learn Pythagoras Theorem. Nowadays puzzles can be made easily using the Formulator Tarsia software. This software provides various geometric and domino puzzle templates. The teacher can choose the shape of the puzzle according to the needs and number of pairs of questions and answers that will be presented. Various templates provided by Formulator Tarsia can be seen in the figure 1 below.

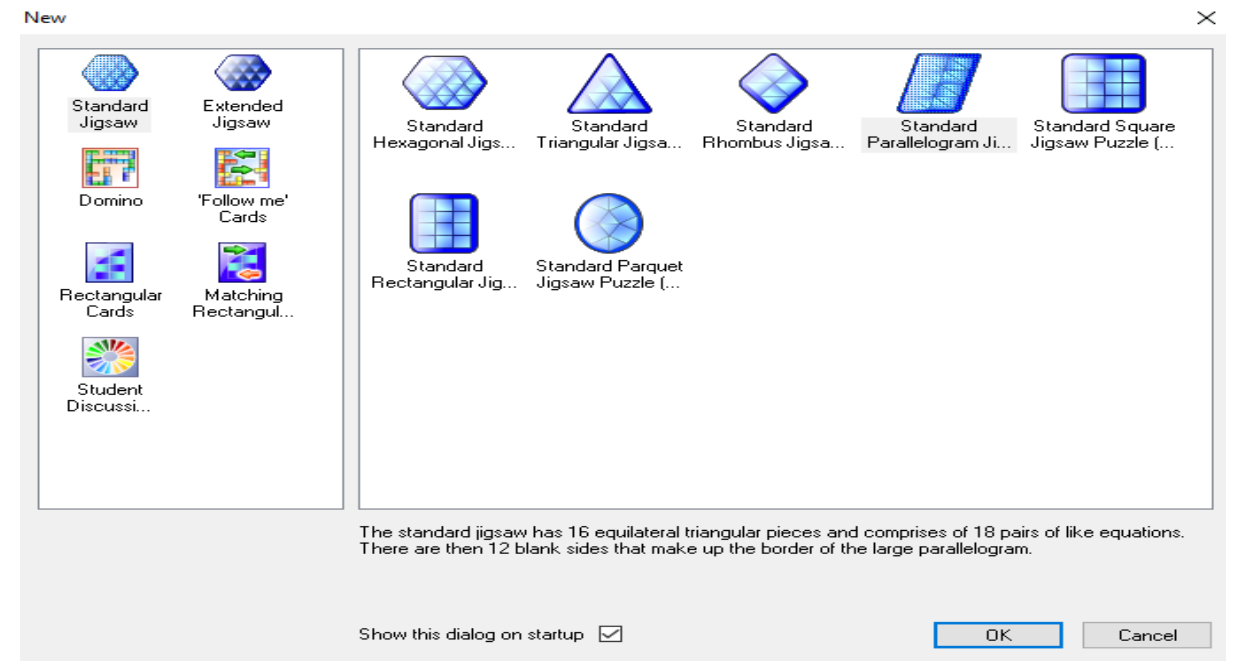

Figure 1. Puzzle templates provided by Formulator Tarsia

The left side of figure 1 contains the basic template of the Tarsia puzzle. If one of the templates is clicked, various puzzle shapes will appear as seen in the right side of the figure above.

Formulator Tarsia is free licence software. It contains the equation editor for creating the mathematics expressions. This software allows easy support for teachers and provides them new perspectives to development of their teaching innovations (Hermitech Laboratory, 2003). Puzzles created using Formulator Tarsia can be presented in printable form and easy to cut out. Tarsia puzzle is separated into smaller fragments. Each side of the fragments contains clues or statement that need to be matched to one another to form a certain shape. It can be used as instructional media in hands on activity. Examples of mathematics Tarsia puzzle are shown in the figure 2 and 3 below. 


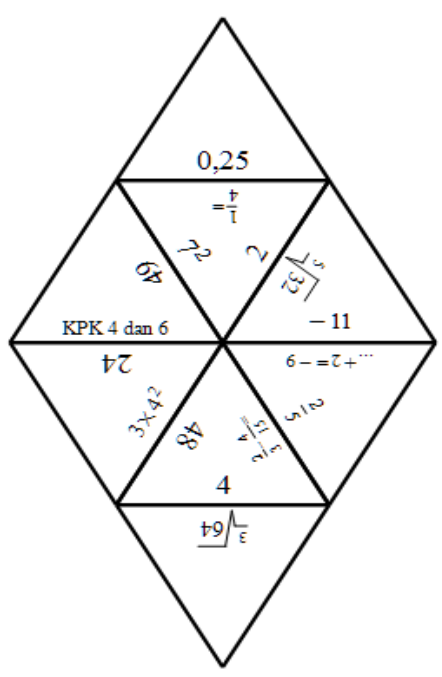

Figure 2. Example of rhombus puzzle

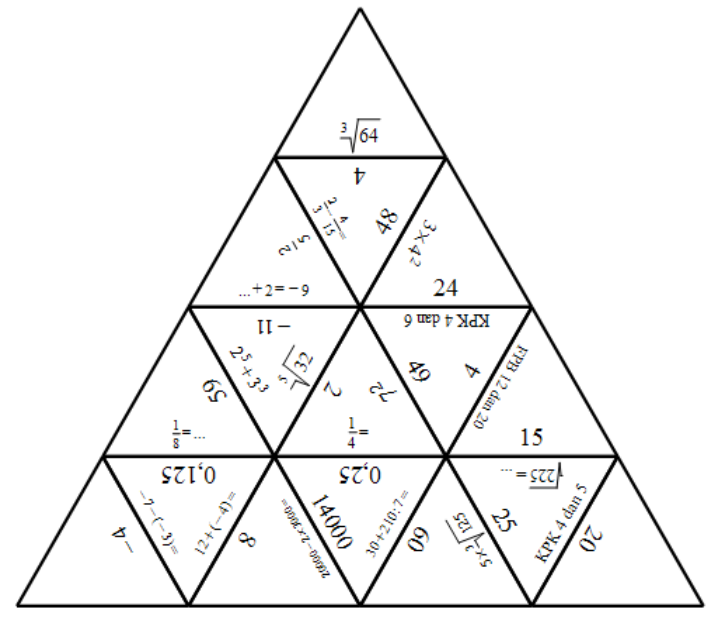

Figure 3. Example of triangular puzzle

Technology enriches the classroom with a lot of educational software that can be used to achieve learning goals (Setyaningrum \& Waryanto, 2017). Teachers need to be more creative in integrating pedagogy and technology to boost students' interest (Buckley \& Doyle, 2016). Technology in education helps teachers in providing instructional media that matches the levels, needs, and diversity of students (Lee, 2017). However, some teachers still have difficulty in integrating technology in teaching and learning process. Teachers need to be encouraged to integrate technology in designing learning strategy that is more effective and enjoyable. Elementary school teachers need to improve their technology skills since the technology and education quality improves better and faster day by day. Factors that influence teacher decisions in integrating technology for instruction are their school culture, confidence using technology, and beliefs about technology in teaching (Howard \& Mozejko, 2015). The introduction of learning software starting from the simple one is expected to foster teacher confidence in using technology. Formulator Tarsia is an easy-to-use software. The product of this software is easy to implement in class as well.

Trigwell (2012) stated that the confidence that teachers get from positive feelings about teaching can encourage them to adopt various learning approaches that appropriate to their students' needs. Therefore this research focused on how elementary school teachers' perceptions of the use of Tarsia puzzles to create joyful learning of mathematics and their response to the Formulator Tarsia as a new technology that can be utilized to design learning activities. In this research, elementary school teachers solved mathematics puzzles created by Formulator Tarsia in a small group. After completing the puzzle, elementary school teachers were introduced to the Formulator Tarsia.

\section{METHOD}

This survey research uses a quantitative approach that emphasizes the 
use of self-report measures on research respondents. The respondents of this research were 42 teachers who teach at different elementary school in Bangkalan, Madura. These teachers are school representatives who have been appointed by Education and Cultural Office of Bangkalan to attend teacher professional training on innovative learning. Among these teachers, there were 14 teachers who have used puzzles in the learning process. However, all teachers have never known the Formulator Tarsia software.

Respondents completed the Tarsia puzzle in groups consist of 4-5 persons and got a tutorial on using the Formulator Tarsia software, from introducing the basic menu bar and toolbar function to steps to create various kinds of puzzles. Through this activity, teachers gained experience on how to solve the Tarsia puzzle and how to create it using Formulator Tarsia. Then, they were asked to fill a questionnaire consist of 16 closeended items to find out their perceptions about the use of Tarsia puzzle in mathematics learning based on their experiences in solving puzzles in groups. The questionnaire also contained the teachers' responses to the Formulator Tarsia as a new technology. Statement items about teachers' perception are modified from previous research conducted by Wei et al. (2011), Howard \& Mozejko (2015), Stoten (2017), (Gorev, 2018), and (Bhakti et al., 2019). The statements in the questionnaire were presented in the form of positive and negative statements (Table 1).

Table 1. Distribution of statements in the questionnaire

\begin{tabular}{ccc}
\hline Aspect & Positive Statement & Negative Statement \\
\cline { 2 - 3 } & Item number & Item number \\
\hline Joyful Learning & $1,3,5,7,9$ & $2,4,6,8,10$ \\
\hline Formulator Tarsia Software & $11,13,15$ & $12,14,16$ \\
\hline
\end{tabular}

The questionnaire uses a Likert scale 1-4. The scoring responses on positive and negative statements are presented in table 2 . The data were analyzed with descriptive statistics that include the percentages and the mean score in every aspect. The mean score was concluded based on the category on Table 3.

Table 2. Scoring Guidance

\begin{tabular}{ccccc}
\hline \multirow{2}{*}{ Statement } & \multicolumn{4}{c}{ Response } \\
\cline { 2 - 5 } & $\begin{array}{c}\text { Strongly } \\
\text { Agree }\end{array}$ & Agree & Disagree & $\begin{array}{c}\text { Strongly } \\
\text { Disagree }\end{array}$ \\
\hline Positive & 4 & 3 & 2 & 1 \\
\hline Negative & 1 & 2 & 3 & 4 \\
\hline
\end{tabular}

Table 3. Criteria of Elementary School Teachers' Perception

\begin{tabular}{cc}
\hline Score $(x)$ & Criteria \\
\hline $1 \leq x \leq 2$ & Poor \\
$2<x \leq 3$ & Fair \\
$3<x \leq 4$ & Good \\
\hline
\end{tabular}




\section{RESULTS AND DISCUSSION}

Elementary school teachers solved mathematics puzzle created by Formulator Tarsia in a small group consist of 4-5 persons. Tarsia puzzle was presented in colorful paper to make them look attractive. The puzzle contains questions and answers about elementary mathematics, such as arithmetic, fraction, and geometry. Each teacher seemed enthusiastic and involved in solving the puzzle. Figure 4 and 5 show the Tarsia puzzle completion process.

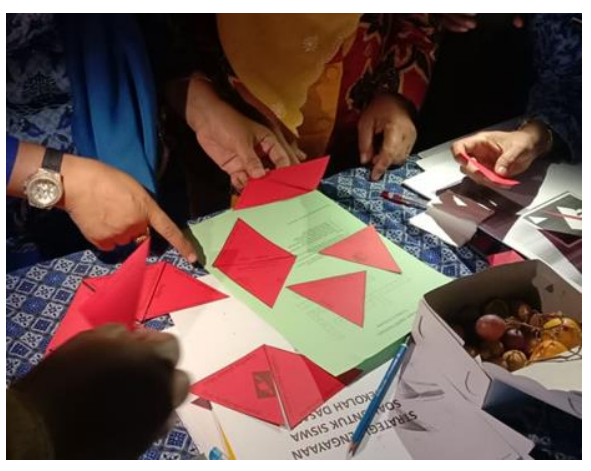

Figure 4. Teachers' Activity

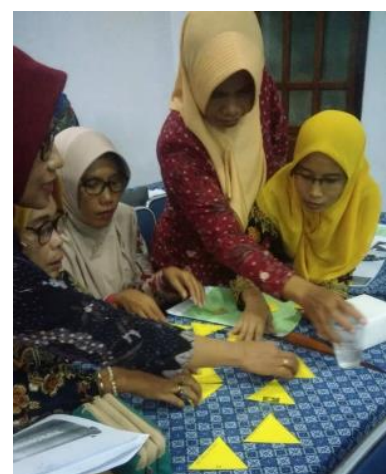

Figure 5. Teachers' Activity

The results of the questionnaire are presented as a percentage of the number of teachers who responded to certain statements as shown in the Table 4.

Table 4. Percentage of Teachers' Perception of Tarsia Puzzle

\begin{tabular}{|c|c|c|c|c|}
\hline \multirow[b]{2}{*}{ Statement item } & \multicolumn{4}{|c|}{ The number of respondents (\%) } \\
\hline & $\begin{array}{l}\text { Strongly } \\
\text { Agree }\end{array}$ & Agree & Disagree & $\begin{array}{l}\text { Strongly } \\
\text { Disagree }\end{array}$ \\
\hline $\begin{array}{l}\text { 1. Tarsia puzzle can be used in mathematics } \\
\text { instructional in elementary school level. }\end{array}$ & 85.7 & 14.3 & 0.0 & 0.0 \\
\hline $\begin{array}{l}\text { 2. Students and teachers feel pressured in } \\
\text { learning process using Tarsia puzzle. }\end{array}$ & 0.0 & 4.8 & 23.8 & 71.4 \\
\hline $\begin{array}{l}\text { 3. Students have opportunity to create their } \\
\text { own strategy to solve Tarsia puzzle. }\end{array}$ & 38.1 & 54.8 & 7.1 & 0.0 \\
\hline $\begin{array}{l}\text { 4. Tarsia puzzle cannot be used in outdoor } \\
\text { learning setting. }\end{array}$ & 0.0 & 7.1 & 38.1 & 54.8 \\
\hline $\begin{array}{l}\text { 5. Students will engage to the classroom } \\
\text { activity using Tarsia puzzle. }\end{array}$ & 40.5 & 52.4 & 7.1 & 0.0 \\
\hline $\begin{array}{l}\text { 6. Tarsia puzzle is too complicated for } \\
\text { elementary school students. }\end{array}$ & 9.5 & 11.9 & 50.0 & 28.6 \\
\hline $\begin{array}{l}\text { 7. Tarsia puzzle can arouse students' } \\
\text { enthusiasm. }\end{array}$ & 66.7 & 16.7 & 9.5 & 7.1 \\
\hline $\begin{array}{l}\text { 8. Students cannot develop creativity in } \\
\text { solving Tarsia puzzles. }\end{array}$ & 14.3 & 19.0 & 50.0 & 16.7 \\
\hline $\begin{array}{l}\text { 9. Students and teachers can find the } \\
\text { pleasure in teaching and learning } \\
\text { mathematics using Tarsia puzzle. }\end{array}$ & 76.2 & 23.8 & 0.0 & 0.0 \\
\hline $\begin{array}{l}\text { 10. Tarsia puzzle can reduce student } \\
\text { enthusiasm for learning. }\end{array}$ & 7.1 & 9.5 & 31.0 & 52.4 \\
\hline 11.I can use Formulator Tarsia to prepare & 26.2 & 52.4 & 19.0 & 2.4 \\
\hline
\end{tabular}




\begin{tabular}{lllll}
\hline \multicolumn{1}{c}{ Statement item } & \multicolumn{4}{c}{ The number of respondents (\%) } \\
\cline { 2 - 6 } & $\begin{array}{c}\text { Strongly } \\
\text { Agree }\end{array}$ & Agree & Disagree & $\begin{array}{c}\text { Strongly } \\
\text { Disagree }\end{array}$ \\
\hline activity in mathematics classroom. & & & & \\
\hline 12. Formulator Tarsia is difficult to use. & 16.7 & 23.8 & 38.1 & 21.4 \\
\hline $\begin{array}{l}\text { 13. Formulator Tarsia enhance } \\
\text { professional development. }\end{array}$ & 21.4 & 69.0 & 4.8 & 4.8 \\
\hline $\begin{array}{l}\text { 14. Formulator Tarsia is not helpful to create } \\
\text { instructional media. }\end{array}$ & 9.5 & 9.5 & 40.5 & 40.5 \\
\hline $\begin{array}{l}\text { 15.I have sufficient technological competence } \\
\text { to use Formulator Tarsia. }\end{array}$ & 9.5 & 52.4 & 23.8 & 14.3 \\
\hline $\begin{array}{l}\text { 16.I am not confident using the Tarsia } \\
\text { Formulator to design learning activities. }\end{array}$ & 9.5 & 16.7 & 45.2 & 28.6 \\
\hline
\end{tabular}

The mean score on each aspect is calculated in order to determine teachers' perceptions The mean score of each aspect can be seen briefly on Table 5.

Table 5. Mean Score of Teachers' Perception of Tarsia Puzzle

\begin{tabular}{lcc}
\hline \multicolumn{1}{c}{ Aspect } & $\begin{array}{c}\text { Average } \\
\text { Score }\end{array}$ & Criteria \\
\hline Joyful Learning & 3.38 & Good \\
can be used for elementary school students & 3.42 & Good \\
create fun athmosphere & 3.71 & Good \\
encourage creativity & 3.00 & Fair \\
arouse enthusiasm & 3.36 & Good \\
can be used in outdoor learning setting & 3.48 & Good \\
students' engagement & 3.33 & Good \\
\hline Formulator Tarsia & $\mathbf{2 . 8 9}$ & Fair \\
Confidence & 2.84 & Fair \\
Belief & 2.94 & Fair \\
\hline
\end{tabular}

The results obtained in this study indicate that elementary school teachers have good perception towards Tarsia puzzle in mathematics learning. Teachers' response towards the Formulator Tarsia as software for making various kinds of puzzles included in the fair category which indicate a positive perception as well.

According to the findings obtained in this research, the majority of teachers agree that Tarsia puzzle can be used in learning mathematics at the elementary school level. However, there are some teachers who have the perception that Tarsia puzzle is too complicated for elementary school students. In order to solve the Tarsia puzzle, students not only think about the solution of the mathematical problems presented, but also have to arrange the puzzle pieces into certain geometric shapes. This is the teacher's concern about implementing Tarsia puzzle in elementary school, because if the task is too complicated for students, it will take up a lot of time. Gorev (2018) stated that puzzle can be used on particular mathematics topics, so it is not necessary to be done on every topic. In selecting the tarsia puzzle according to the grade level, the teacher must be 
very careful. Puzzles must not be out of context, learning objectives and must have an effect on students. Tarsia puzzle can be use as a medium to train and find out students' understanding. Before implementing this, teacher must ensure that students have learned the concepts presented in the puzzle.

From a total of 42 respondents, $16.6 \%$ of them have the perception that Tarsia puzzle can reduce student enthusiasm for learning. Basically, puzzles can be designed according to students' needs. Teachers need to identify the difficulty level of the problem that will be presented in the puzzle. Complex problems should be presented through a simple puzzle. Conversely, a simple problem can use a more difficult puzzle template. This is done to anticipate the decreasing in student enthusiasm because they face difficulty in solving problems in the form of puzzle. In this case, the teacher has an important role in presenting Tarsia puzzle in accordance with the level of student thinking and the difficulty level of the problem. Around $83.4 \%$ of respondents believe that the use of Tarsia puzzle can arouse students' enthusiasm. While completing the puzzle in groups, all respondents seemed enthusiastic and focused on solving the puzzle. This is in line with respondents' perceptions that the use of Tarsia puzzles can make students more engaged to the classroom activity. Tarsia puzzles will make students more active in learning.

The main concepts of joyful learning are the creation of a pleasant atmosphere and there is no burden for teachers and students in learning (Wei et al., 2011). According to the respondents' perception, learning process with Tarsia puzzle meets this criterion. This is supported by data that $76.2 \%$ of the total respondents stated strongly agree and the rest stated agreed to that statement "students and teachers can find the pleasure in learning mathematics using Tarsia puzzle". Otherwise, 71,4\% of respondents strongly disagree that students and teachers feel pressured in learning process using Tarsia puzzle. This facts indicate that there is no burden for teachers and students in learning mathematics using Tarsia puzzle. Teachers' enjoyment of teaching has many positive implications for their classroom instruction and environment (Russo et al., 2020). Enjoyment of teaching not only encourage teachers to improve the quality of their instruction, but also can increase student enjoyment of learning (Frenzel et al., 2016).

Many researchers developed various educational games based on pedagogical theories and strategies with joyful learning features (Chen \& Tsai, 2009). The positive perception of elementary school teachers towards the use of Tarsia puzzles in learning has led to the features of joyful learning. In joyful learning, there is a bond between teachers and students and among students and the learning situation (Yabo, 2020). In other words, Tarsia puzzle will be able to create a pleasant learning atmosphere. According to $92.9 \%$ of respondents, Tarsia puzzles can also be used in outdoor learning. Activity with puzzle can be very time consuming to be applied in the mathematics classroom. However, there is potential to solve 
the puzzle at home as a variation of student task. In distance learning such as in the current pandemic era, tarsia puzzle can be used as an alternative learning media. Teachers or parents can make various puzzles using the Formulator Tarsia to keep students active, motivated, and not bored while studying at home. This puzzle can make students learn mathematics not only from their gadget but also through hands-on activities.

Based on these facts, it can be concluded that the Tarsia puzzle can be used as an instructional media that supports the creation of joyful learning of mathematics. Elementary school teachers have a good or positive perception (average score $=3.38$ ) of the use of Tarsia puzzles in mathematics classroom with joyful learning strategy. This is in line with the results of research conducted by Stoten (2017) which received very positive responses from both undergraduate and MBA students who see Tarsia puzzle as a fun activity that increase their ability to recall information.

In the current digital era, teachers not only need to develop their technical competencies, but their perspectives on the integration of technology in mathematics learning must be developed as well (Ghavifekr et al., 2015). Based on their average response score (average score $=2.89$ ) on the use of the Formulator Tarsia, their perception of the software is in the fair criteria. The majority of respondents agree that the Formulator Tarsia can enhance their professional development and help them to create instructional media that make the learning process more interesting. According to Cope (2015) learning media and manipulatives help teachers to represent mathematical concepts Most of respondents believe that they can use the Formulator Tarsia to prepare activities in mathematics classroom. Teachers are more likely to feel the benefit of technologies in teaching and learning, if these beliefs are supported and strengthened by their peers and the school (Zhao et al., 2003).

Technology provides unique challenges and benefits to the teaching and learning of mathematics (Hill et al., 2020). Tarsia puzzle is suitable for deepening concepts understanding. Teachers can present problems through this puzzle after students learn new concepts. Students can learn new concepts and procedures without technology and then progress to using technology to deepen understanding or provide a more efficient method of solving problems (Ball \& Stacey, 2005). Although some teachers feel they have sufficient technological competence to use the Formulator Tarsia, but some others feel less confident and competent in using Formulator Tarsia to design mathematics learning activities. Teachers can increase their confidence by practicing the software step by step. Teachers' positive perception of the use of the Formulator Tarsia is expected to encourage them to learn and foster their confidence in using technology. Teacher confidence is very important as teachers who are more confident using technology are more likely to integrate technology in their teaching activities (Howard \& Mozejko, 2015). 


\section{CONCLUSION}

Based on elementary school teachers' perception, Tarsia puzzle designed by Formulator Tarsia could be used to create joyful learning of mathematics. Problem solving through Tarsia puzzle is considered fun and encourages students to be more eager to learn and be engaged in classroom activities. Tarsia puzzle can be used both inside and outside the classroom. Elementary school teachers had positive responses to the Formulator Tarsia software as new software to create various puzzle activities. However, some of them stated that they had lack of confidence and competence in using Formulator Tarsia. They need to practice applying the software to increase their confidence because the confidence using technology is one of the factors that influence teacher decisions in integrating technology for instruction.

\section{REFERENCES}

Ariawan, V. A. N., \& Pratiwi, I. M. (2017). Implementing Joyful learning Strategy Using Treasure Clue Game Method in Order to Improve Reading Comprehension Skill. Jurnal Prima Edukasia, 5(2), 203-210. https:/ / dx.doi.org/10.21831/jpe.v5i2.11601

Asri, D. C., Rahman, B., \&Wijaya, S. (2020). Perbedaan Kemampuan Berpikir Kreatif Melalui Pembelajaran Matematika Berbantuan Puzzle $\begin{array}{llll}\text { dan } \quad \text { Geogebra. } & \text { Vygotsky, }\end{array}$ http:/ / dx.doi.org/10.30736/vj.v2i2.223

Ball, L \& Stacey, K. (2005). Technology-supported mathematics learning environment. Reston, VA: NCTM.

Berney, S., \& Bétrancourt, M. (2016). Does animation enhance learning? A meta-analysis. Computers and Education, 101, 150-167. https:/ / doi.org/10.1016/j.compedu.2016.06.005

Bhakti, C. P., Ghiffari, M. A. N., \& Salsabil, K. (2019). Joyful Learning: Alternative Learning Models to Improving Student's Happiness. Jurnal VARIDIKA, 30(2), 30-35. https://doi.org/10.23917/varidika.v30i2.7572

Buckley, P., \& Doyle, E. (2016). Gamification and student motivation. Interactive Learning Environments, 24(6), 1162-1175. https:/ / doi.org/10.1080/10494820.2014.964263

Candiasa, I.M., Satiyadnya, N., \& Sunu, G.K.A. (2018). Using puzzle to encourage students to do problem posing. IOP Conf. Series: Journal of Physics Series 1040. https://doi.org/10.1088/17426596/1040/1/012025

Chen, A. N. \& Tsai, C. (2009). Knowledge infrastructure of the future (Guest Editorial). Journal of Educational Technology \& Society, 12(1), 1-4.

Clark, R. C., \& Mayer, R. E. (2008). Learning by viewing versus learning by doing: Evidence-based guidelines for principled learning environments. Performance Improvement, 47(9), 5-13. https:/ / doi.org/10.1002/pfi.20028

Cope, L. (2015). Math Manipulatives: Making The Abstract Tangible. Delta 
Journal of Education, 5(1), 10-19

Frenzel, A. C., Pekrun, R., Goetz, T., Daniels, L. M., Tracy, L., Becker-kurz, B., \& Klassen, R. M. (2016). Measuring Teachers' Enjoyment, Anger, and Anxiety: The Teacher Emotions Scales (TES). Contemporary Educational Psychology, https://doi.org/10.1016/j.cedpsych.2016.05.003

Ghavifekr, S., Athirah, W., \& Rosdy, W. (2015). Teaching and Learning with Technology: Effectiveness of ICT Integration in Schools. International Journal of Research in Education and Science (IJRES), 1(2). 175-191

Gorev, P. M. (2018). Puzzles as a Didactic Tool for Development of Mathematical Abilities of Junior Schoolchildren in Basic and Additional Mathematical Education. EURASIA, 14(10), 1-12. https://doi.org/10.29333/ejmste/93675

Hasler, H. M., \& Akshoomoff, N. (2019). Mathematics ability and related skills in preschoolers born very preterm. Child Neuropsychology, 25(2). 162-178. https:// doi.org/10.1080/09297049.2017.1412413

Hermitech Laboratory. (2003). Information on Formulator Tarsia. Retrived from http://www.mmlsoft.com/index.php/products/tarsia

Hill, J. E. \& Uribe-florez, L., U. (2020). Understanding Secondary Teachers' TPACK and Technology Implementation in Mathematics Classrooms. International Journal of Technology in Education (IJTE), 3(1), 1-13.

Howard, S. K. \& Mozejko, A. (2015). Teachers: technology, change and resistance. In M. Henderson \& G. Romeo (Eds.), Teaching and Digital Technologies: Big Issues and Critical Questions (pp. 307-317). Port Melbourne, Australia: Cambridge University Press.

Kirikkaya, E. B., Işeri, Ş., \& Vurkaya, G. (2010). A board game about space and solar system for primary school students. Turkish Online Journal of Educational Technology, 9(2), 1-13.

Lee, J. E. (2017). Preschool Teachers ' Pedagogical Content Knowledge in Mathematics. International Journal of Early Childhood. https://doi.org/10.1007/s13158-017-0189-1

OECD. (2019). PISA 2018 Results. Combined Executive Summaries. Journal of Chemical Information and Modeling, 53(9), 1689-1699, www.oecd.org/about/publishing/corrigenda.htm

Putra, I. S. (2020). Improve Student's Learning Using Media for Understanding and Interest in Pythagorean Theorem Learning. Vygotsky, 2(2), 66-77. https://doi.org/10.30736/vj.v2i2.222

Putri, R.S., Purwanto, A., Pramono, R., Asbari, M., Wijayanti, L. M., \& Choi, C. H. (2020). Impact of the COVID-19 Pandemic on Online Home Learning: An Explorative Study of Primary Schools in. International Journal of Advanced Science and Technology, 29(5), 4809 4818.

Rasmitadila, Aliyyah, R.R., Rachmadtullah, R., Samsudin, A., Syaodih, E., Nurtanto, M., \& Tambunan, A.R.S., (2020). The Perceptions of Primary School Teachers of Online Learning during the COVID-19 Pandemic Period: A Case Study in Indonesia, Journal of Ethnic and Cultural 
Studies, 7(2), 90 - 109, https:/ / doi.org/10.29333/ejecs/388

Russo, J., Bobis, J., Sullivan, P., Downton, A., Livy, S., McCormick, M., \& Hughes, S. (2020). Exploring the relationship between teacher enjoyment of mathematics, their attitudes towards student struggle and instructional time amongst early years primary teachers. Teaching and Teacher Education, 88, 102983. https://doi.org/10.1016/j.tate.2019.102983

Sengul, S., \& Argat, A. (2015). The Analysis of Understanding Factorial Concept Processes of 7 th Grade Students who have Low Academic Achievements with Pirie Kieren Theory. Procedia - Social and Behavioral Sciences, 197 (February), 1263 - 1270. https:// doi.org/10.1016/j.sbspro.2015.07.398

Setyaningrum, W. \& Waryanto, N. H. 2017. Developing Mathematics Edutainment Mediafor Android based on Students Understanding and Interest: A Teachers"e Review. IOP Conf. Series: Journal of Physics Series 983, https://doi.org/ 10.1088/1742-6596/983/1/012093

Simamora, R. E., Saragih, S., \& Hasratuddin, H. (2018). Improving Students' Mathematical Problem Solving Ability and Self-Efficacy through Guided Discovery Learning in Local Culture Context. International Electronic Journal of Mathematics Education, 14(1), 61-72. https:/ / doi.org/10.12973/iejme/3966

Stoten, D. W. (2017). Tarsia : An Interactive and Engaging Activity That Promotes Consolidation of Knowledge. Management teaching Review, 1-10. https:/ / doi.org/10.1177/2379298117697000

Trigwell, K. (2012). Relations between teachers' emotions in teaching and their approaches to teaching in higher education. Instructional Science, 40(3), 607-621. https:/ / doi.org/10.1007/s11251-011-9192-3

UNESCO Institute for Statistics. (2017). Literacy rates continue to rise from one generation to the next. UNESCO. Retrived from http://uis.unesco.org/en/news/international-literacy-day2017

Widyawulandari, R., -, S., \& Indriayu, M. (2019). Implementation of Joyful Learning Approach in Providing Learning Motivation for Elementary School Student. Advances in Social Science, Education and Humanities Research, 277, 54-58. https://doi.org/10.2991/steach18.2019 .12

Wei, C. W., Hung, I. C., Lee, L., \& Chen, N. S. (2011). A joyful classroom learning system with robot learning companion for children to learn mathematics multiplication. Turkish Online Journal of Educational Technology, 10(2), 11-23.

Yabo, R. S. (2020). The Joyful Experience in Learning Mathematics. Southeast Asian Mathematics Education Journal, 10(1), 55 - 68, https:// doi.org/10.46517/ seamej.v10i1.85

Zhao, Y. \& Frank, K. A. (2003). Factors Affecting Technology Uses in Schools: An Ecological Perspective. American Educational Research Journal, 40(4), 80 - 840, https:/ / doi.org/10.3102/00028312040004807 